\title{
Pelatihan Perbanyakan Tanaman Buah secara Vegetatif dengan Teknik Penyambungan (Grafting) di Panti Asuhan Yayasan Islam Media Kasih Banda Aceh
}

\author{
Lukmanul Hakim ${ }^{1}$, Fadlan Hidayat ${ }^{*}$, Ruka Yulia ${ }^{1}$, Chairunni AR $^{2}$ \\ ${ }^{1}$ Program Studi Teknologi Pangan, Universitas Serambi Mekkah \\ ${ }^{2}$ Program Studi Teknologi Industri Pertanian, Universitas Serambi Mekkah \\ Jl. Unmuha, Batoh, Banda Aceh, kode pos 23245 \\ *email korespodensi: fadlanhidayat@serambimekkah.ac.id \\ DOI: $10.32672 /$ btm.v1i2.1307
}

\begin{abstract}
The community service activity carried out by the Faculty of Agricultural Technology of the Serambi Mekkah University partnered with the Media Kasih Islamic Foundation, Gampong Seutui, Baiturrahman District, Banda Aceh. The activity provides information about the propagation of generative and vegetative from fruit plants. Besides providing the information, the team also assisted orphanage in conducting practices directly in vegetative propagation of fruit plants using grafting techniques. This activity was carried out on Sunday, July 21,2019 . Participants in this activity were orphanage who participated in \pm 15 chidren. The orphanage were very enthusiastic to attend this activity to get many informations through discussion the material and practice the grafting techniques. This activity provides an understanding of the methods of generative and vegetative fruit plant propagation. The benefits of this activity are to understand the generative and vegetative methods and to practice the method of propagation by grafting techniques.
\end{abstract}

Keywords: Multiplication, Vegetative, Grafting, Orphanage

\section{Abstrak}

Kegiatan pengabdian kepada masyarakat yang dilakukan di oleh pihak Fakultas Teknologi Pertanian Universitas Serambi Mekkah bermitra dengan Panti Asuhan Yayasan Islam Media Kasih Gampong Seutui Kecamatan Baiturrahman Kota Banda Aceh. Kegiatan tersebut memberikan informasi tentang perbanyakan tanaman buah secara generatif dan vegetatif. Selain memberikan informasi, tim pelaksana kegiatan juga mendampingi anak-anak panti asuhan dalam melakukan praktek langsung mengenai perbanyakan tanaman buah secara vegetatif dengan teknik penyambungan (grafting). Kegiatan ini dilakukan pada hari minggu, 21 Juli 2019. Peserta kegiatan ini adalah anak-anak panti asuhan yang berjumlah \pm 15 orang. Anak-anak panti sangat berantusias dalam mengikuti kegiatan untuk mendengarkan penjelasan materi sampai dengan melakukan praktek langsung. Kegiatan ini bertujuan memberikan pemahaman terhadap metode perbanyakan tanaman buah secara generatif dan vegetatif. Manfaat dari kegiatan ini yaitu memahami metode pebanyakan secara generatif 
Lukmanul Hakim, dkk.

dan vegetatif, praktek cara perbanyakan dengan teknik penyambungan (grafting).

Kata Kunci: Perbanyakan, Vegetatif, Grafting, Panti Asuhan

\section{PENDAHULUAN}

Kegiatan Penangkaran/ pembibitan tanaman buah pada umumnya dilakukan secara berkelompok dan turun-menurun, dengan manajemen tradisional dan teknik penangkaran bibit yang sederhana (Kusuma dan Wuryanto, 2019). Keterampilan dan kecepatan seorang penangkar benih dalam melakukan penyambungan sangat menentukan keberhasilan sebuah penangkaran bibit (Prastowo dan Roshetko, 2006).

Pada prinsipnya perbanyakan tanaman banyak dilakukan dengan berbagai cara, mulai dengan yang sederhana sampai yang rumit. Perbanyakan tanaman bisa digolongkan menjadi dua golongan besar, yaitu perbanyakan secara generatif dan vegetatif. Perbanyakan tanaman buah yang popular di kalangan penangkar benih tanaman buah-buahan di Indonesia adalah okulasi dan sambung pucuk (grafting) karena caranya mudah dan tingkat keberhasilannya cukup tinggi (Sukarmin dkk., 2010).

Perbanyakan generatif sudah banyak dilakukan dengan cara penyemaian biji untuk dijadikan tanaman baru. Jika menggunakan biji hasil buangan yang tidak diketahui sifat dan kelebihannya maka akan mengecewakan pada saat berbuah. Untuk menghindari kelemahan yang terdapat pada perbanyakan generatif maka orang mulai memindahkan perhatiannya perbanyakan vegetatif. Alternatif yang dapat diupayakan adalah peningkatan pengelolaan kebun buah-buahan dengan penggunaan bibit bermutu melalui perbanyakan vegetatif (Samekto, dkk., 1995)

Perbanyakan vegetatif pada tanaman dapat menghasilkan bibit tanaman dalam jumlah besar dan mempunyai kesamaan sifat dengan tanaman induk yang dipakai sebagai entris. Batang induk yang dipakai adalah batang induk yang sehat (Ismail, 2017). Kelebihan bibit dari hasil perbanyakan vegetatif dibanding cara generatif (biji) adalah : (1) Umur berbuah lebih cepat. (2) Aroma dan cita rasa buah tidak menyimpang dari sifat induknya. (3) Diperoleh individu baru dengan sifat unggul lebih banyak, misalnya batang bawah (rootstock) yang unggul perakarannya disambung dengan batang atas (entris, scion) yang unggul produksi buahnya dan bahkan dapat divariasikan (Rukmana, 1999).

Grafting adalah salah satu teknik perbanyakan vegetatif menyambungkan batang bawah dan batang atas dari tanaman yang berbeda sedemikian rupa sehingga tercapai persenyawaan, kombinasi ini akan terus tumbuh membentuk tanaman baru. Menurut Prastowo, dkk., (2006) Penyambungan atau enten (grafting) adalah penggabungan dua bagian tanaman yang berlainan sedemikian rupa sehingga merupakan satu kesatuan yang utuh dan tumbuh sebagai satu tanaman setelah terjadi regenerasi jaringan pada bekas luka sambungan atau tautannya.

Seni grafting telah digemari sejak dua abad yang lalu, yaitu sekitar abad ke-15 menggambarkan betapa pelik dan banyaknya ragam dari seni grafting (Wudianto, 2002).

Penyambungan antar varietas (masih dalam satu species) tidak pernah mengalami kesulitan. Demikian juga bila kita melakukan penyambungan dua tanaman 102 
BAKTIMAS

Jurnal Pengabdian pada Masyarakat
Vol. 1, No. 2,

Agustus 2019
eISSN 2685-113x

pISSN 2685-0303

yang jenis atau speciesnya lain tapi masih dalam satu marga, tingkat keberhasilannya masih cukup tinggi, walaupun kadang-kadang juga ditemui kegagalan.

\section{METODE}

\section{Bahan dan alat}

Bahan yang digunakan dalam teknik perbanyakan dengan cara penyambungan (grafting) adalah kantong plastik dan tali pengikat. Sedangkan bahan yang digunakan adalah gunting, pisau dan batu asahan.

\section{Metode}

Pengabdian kepada masyarakat ini dilakukan oleh tim Fakultas Teknologi Pertanian dan dibantu oleh beberapa mahasiswa bermitra dengan Panti Asuhan Media Kasih di Gampong Seutui Kecamatan Baiturrahman Kota Banda Aceh, kegiatan yang dilakukan meliputi penyuluhan tentang perbanyakan tanaman buah.

Kegiatan Pengabdian kepada Masyarakat yang dilakukan di Panti Asuhan Media Kasih dengan metode penyampaian materi dan praktek langsung tentang teknik perbanyakan vegetatif tanaman buah secara penyambungan (grafting).

Tim pelaksana kegiatan memberikan materi mengenai teknik perbanyakan generatif dan vegetatif pada tanaman buah secara mandiri. Pada penyuluhan lebih fokus pada perbanyakan dengan cara penyambungan (grafting) pada buah mangga dan beberapa tanaman buah yang ada disekitar panti.

Setelah memberi materi tentang perbanyakan vegetatif dengan teknik penyambungan (grafting), tim pelaksana kegiatan mempraktekkan langsung.

Kegiatan tersebut direspon positif oleh pihak panti asuhan, sehingga anak-anak panti sangat berantusias dan mereka mempraktekkan langsung teknik penyambungan (grafting) pada tanaman buah yang dipandu oleh tim pelaksana kegitan.

\section{HASIL DAN PEMBAHASAN}

Kegiatan pengabdian kepada masyarakat dilakukan di Panti Asuhan Media Kasih di Gampong Seutui Kecamatan Baiturrahman Kota banda Aceh. Beberapa materi yang disampaikan pada kegiatan tersebut antara lain :

1. Penyuluhan mengenai perbanyakan tanaman buah secara generatif dan vegetatif.

2. Praktek langsung perbanyakan secara vegetatif dengan teknik penyambungan (grafting).

Selama kegiatan penyuluhan di Panti Asuhan tersebut anak-anak panti sangat antusias dalam menyerap materi yang disampaikan. Hal ini terlihat dari banyaknya anak-anak panti yang hadir dalam kegiatan tersebut serta banyaknya meraka yang bertanya dan berdiskusi dengan tim pelaksana kegiatan. Isi materi yang disampaikan dalam kegiatan tersebut diantaranya yaitu perbanyakan tanaman buah secara generatif dan vegetatif yang dapat dilakukan secara mandiri.

Perbanyakan secara vegetatif dengan teknik penyambungan (grafting) keuntungan antara lain : 1). Mengekalkan sifat-sifat klon yang tidak dapat dilakukan pada pembiakan vegetatif lainnya seperti stek, cangkok dan lain-lainnya. 2). Bisa 
Lukmanul Hakim, dkk.

memperoleh tanaman yang kuat karena batang bawahnya tahan terhadap keadaan tanah yang tidak menguntungkan, temperatur yang rendah, atau gangguan lain yang terdapat di dalam tanah. 3). Memperbaiki jenis-jenis tanaman yang telah tumbuh, sehingga jenis yang tidak di inginkan diubah dengan jenis yang dikehendaki. 4). Dapat mempercepat berbuahnya tanaman (untuk tanaman buahbuahan) dan mempercepat pertumbuhan pohon dan kelurusan batang (jika tanaman kehutanan).

Selain keuntungan perbanyakan secara vegetatif dengan teknik penyambungan (grafting) mempunyai kekurangan antara lain : 1). Bagi tanaman kehutanan, kemungkinan jika pohon sudah besar gampang patah jika ditiup angin kencang. 2). Tingkat keberhasilannya rendah jika tidak cocok antara scion dan rootstock (Suwandi, 2009).

Adapun syarat penyambungan antara batang atas dan batang bawah antara lain : a). Syarat batang bawah : 1). Berdiameter 3-5 mm, berumur sekitar 3-4 bulan. 2). Dalam fase pertumbuhan yang optimum (tingkat kesuburannya baik), kambiumnya aktif, sehingga memudahkan dalam pengupasan dan proses merekatnya mata tempel ke batang bawah. 3). Batang bawah dipupuk dengan Urea 1-2 minggu sebelum penempelan. 4). Gunakan polybag ukuran $15 \times 20 \mathrm{~cm}$ yang sanggup bertahan dari biji sampai 3 bulan siap tempel sampai dengan 3 bulan setelah tempel, setelah periode tersebut polybag harus diganti dengan ukuran yang lebih besar $20 \times 30 \mathrm{~cm}$, atau langsung ke polybag 30x40 cm. b). Syarat batang atas : 1). Batang atas atau entres yang akan disambungkan pada batang bawah diambil dari pohon induk yang sehat dan tidak terserang hama dan penyakit. 2). Entres yang akan diambil sebaiknya dalam keadaan dorman (istirahat) pucuknya serta tidak terlalu tua dan juga tidak terlalu muda (setengah berkayu). 3). Entres sebaiknya dipilih dari bagian cabang yang terkena sinar matahari penuh (tidak ternaungi) sehingga memungkinkan cabang memiliki mata tunas yang tumbuh sehat dan subur (Prastowo, dkk., 2006)

Anak-anak panti asuhan sangat merespon kegiatan tersebut. Dari penjelasan mengenai perbanyakan tanaman buah tersebut ada beberapa pertanyaan dari anak-anak panti sehingga muculnya forum diskusi. Kegiatan yang kedua yaitu memperaktekkan langsung cara perbanyakan secara vegetatif dengan teknik penyambungan (grafting). Kegiatan praktek dilakukan oleh anak-anak panti asuhan dengan arahan dari tim pelaksana kegiatan. Sesuai dengan kesepakatan pada saat penyampaian materi yang telah disampaikan pada saat sesi penyampaian materi.

Selanjutnya kita berharap dapat bekerja sama dengan pihak mitra panti asuhan yayasan islam media kasih agar kegiatan seperti ini dapat berlanjut dengan topic kegiatan yang berbeda. Cara perbanyakan secara vegetatif dengan teknik penyambungan (grafting) dapat dilihat pada gambar 1 . 
BAKTIMAS

Jurnal Pengabdian pada Masyarakat
Vol. 1, No. 2,

Agustus 2019
eISSN 2685-113x

pISSN 2685-0303
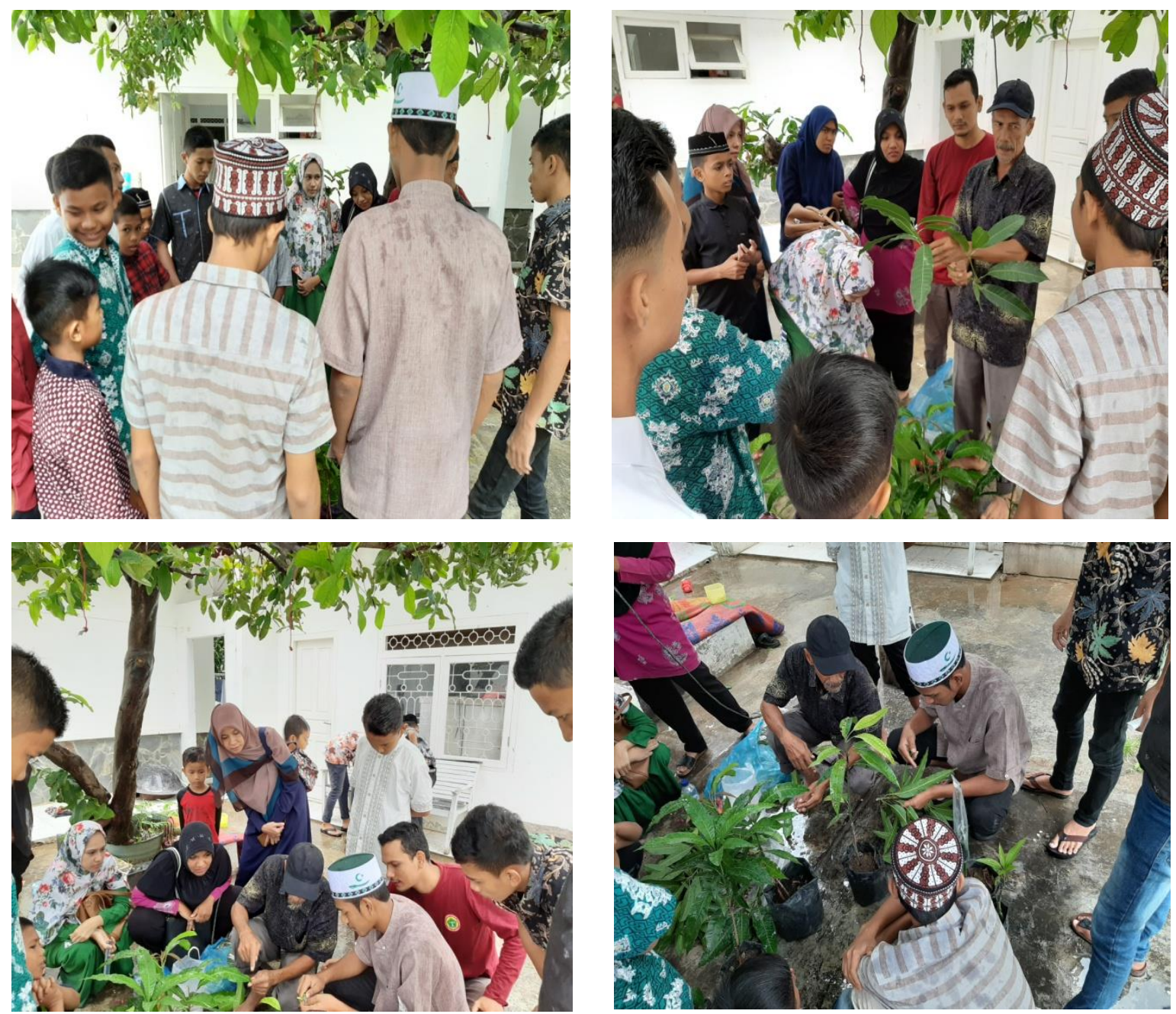

Gambar 1. Proses Teknik Penyambungan (Grafting).

\section{PENUTUP}

Berdasarkan pengabdian yang telah dilakukan dapat disimpulkan bahwa, Kerjasama pengabdian kepada masyarakat antara Tim Pelaksana kegiatan dari Fakultas Teknologi Pertanian Universitas Serambi Mekkah bermitra dengan Panti Asuhan Yayasan Islam Media Kasih Gampong Seutui Kecamatan Baiturrahman Kota Banda Aceh sangat antusias dalam mengikuti kegiatan tersebut. Anak-anak panti asuhan sudah bisa mempraktekkan metode perbanyakan tanaman buah secara vegetatif dengan teknik penyambungan (grafting). Dengan adanya kegiatan seperti ini diharapkan anakanak panti asuhan dapat melakukan perbanyakan tanaman buah yang ada disekitar lingkungan panti asuhan secara mandiri. 
Lukmanul Hakim, dkk.

\section{DAFTAR PUSTAKA}

Ismail, Sembiring, D.S.P.S., Desky, R.S. 2017. Pengaruh Titik Tumbuh Entres dan Teknik Pengikatan terhadap Kecepatan Tumbuh Sambung samping Tanaman Kakao. http://ojs.serambimekkah.ac.id/index.php/serambi$\underline{\text { saintia/article/view/529/484 }}$

Kusuma, I. C dan L. Wuryanto. 2019. Pemberdayaan Masyarakat Berbasis Penyusunan Laporan Keuangan Sederhana Pada Kelompok Usaha Tani Pembibitan Tanaman Buah. Jurnal Qardhul Hasan, Vol. 5, No. 1, hal. 23-27

Prastowo N, J.M. Roshetko. 2006. Teknik Pembibitan dan Perbanyakan Vegetatif Tanaman Buah. World Agroforestry Centre (ICRAF) dan Winrock International, Bogor, Indonesia.

Rukmana, R. 1999. Teknik Memproduksi Bibit Unggul Tanaman Buah-buahan. Penerbit Kanisius. Yogyakarta.

Samekto, H., A. Supriantono dan D. Kristianto. 1995. Pengaruh Umur dan Bagian Semaian Terhadap Pertumbuhan Stek Satu Ruas Batang Bawah Jeruk Japanese Citroen. Jurnal Hortikultura 5 (1): 25-29.

Sukarmin, E. Angriani dan Endriyanto. 2010. Teknik Penyambungan Mangga Arumanis 143 dengan Batang Bawah Mangga Madu dan Saigon. Buletin Teknik Pertanian, Vol. 15, No. 1, hal. 16-18.

Suwandi, 2009. Petunjuk Teknis Perbanyakan Tanaman Dengan Cara Sambungan (Grafting). Instansi Balai Besar Penelitian Bioteknologi dan Pemuliaan Tanaman Hutan. Yogyakarta.

Wudianto, R. , 2002, Membuat Setek, Cangkok dan Okulasi, P. T. Penebar Swadaya, Jakarta. 